\title{
UPAYA MENINGKATKAN KEAKTIFAN DAN PRESTASI BELAJAR SISWA MELALUI PENDEKATAN TEKNIK BERPIKIR, BERPASANGAN, BERBAGI PADA MATA PELAJARAN PKN DI KELAS IV SDN 07 KABAWETAN
}

\author{
Suarjo
}

\begin{abstract}
Abstrak
Penelitian ini bertujuan untuk meningkatan keaktifan belajar dan hasil belajar siswa dalam proses pembelajaran dengan menerapkan pendekatan Teknik Berpikir, Berpasangan, Berbagi dalam pembelajaran PKN dalam pada siswa kelas IV SDN 07 Kabawetan. Penelitian ini merupakan Penelitian Tindakan Kelas (PTK) yang terdiri dari 3 siklus. Subjek penelitiannya adalah siswa kelas IV SDN 07 Kabawetan yang terdiri dari 12 orang pada tahun pelajaran 2014/2015. Pengumpulan data dilakukan melalui lembar observasi dan lembar tes. Observasi dilakukan untuk mengamati aktivitas guru selama kegiatan belajar mengajar berlangsung. Tes ini digunakan untuk mengetahui tingkat keberhasilan siswa. Hasil yang diperoleh dari penelitian yaitu: (1) pada siklus I terdapat 4 kelemahan yang terdapat pada aktivitas guru, serta nilai rata-rata dari hasil tes diperoleh 6,16 dan persentase ketuntasan belajar klasikal 66,66\%dengan kategori belum tuntas; (2) siklus II terdapat 2 kelemahan lagi pada aktivitas guru, serta nilai rata-rata dari hasil tes diperoleh 7,12, dan persentase ketuntasan belajar klasikal 83,33\% dengan kategori belum tuntas; (3) siklus 3 hanya tersisa 1 kelemahan pada aktivitas guru pada saat pembelajaran berlangsung, serta nilai rata-rata diperoleh 8,02 dengan persentase ketuntasan belajar klasikal 91,66\% dalam kategori tuntas. Berdasarkan hasil penelitian tersebut maka penerapan pendekatan Tehnik Berpikir, Berpasangan, Berbagi dapat meningkatkan hasil belajar, aktivitas siswa, dan aktivitas guru serta kualitas proses pembelajaran PKN di kelas IV SDN 07 Kabawetan.
\end{abstract}

Kata Kunci: Peningkatan,, Hasil Belajar, teknik berpikir, berpasangan, berbagi

\section{PENDAHULUAN}

Pendidikan pada hakikatnya adalah sebuah usaha dimana peserta didik diharapkan dapat memecahkan persoalanpersoalan dalam kehidupannya. Tentu dengan harapan agar peserta didik dapat menjadi lebih baik, bisa mengembangkan potensi dirinya dan bermanfaat untuk lingkungannya.

Dalam hal ini menunjukkan bahwa manusia juga membutuhkan pendidikan untuk kehidupannya agar manusia dapat mengembangkan potensi dirinya melalui proses pembelajaran. Seperti yang ditetapkan oleh peraturan UU RI No. 20 tahun 2003 tentang Sistem Pendidikan Nasional bab II Pasal 3 sebagai berikut:

"Pendidikan bertujuan untuk mengembangkan potensi peserta didik agar menjadi manusia yang beriman dan bertaqwa kepada Tuhan Yang Maha Esa, berakhlak mulia, sehat, berilmu, cakap, kreatif, mandiri, dan menjadi warga negara yang demokratis serta 
bertanggung jawab. Tujuan yang diharapkan ini sulit dicapai apabila siswa dianggap sebagai obyek pembelajaran dengan kegiatan yang mengutamakan pembentukan intelektual dan tidak melatih mereka menjadi insan yang kreatif, mandiri, demokratis serta bertanggung jawab.

Ahli pendidikan yakni menurut Bloom (dalam Syaiful Sagala, 2006: 33) berpendapat bahwa tujuan pendidikan yang ingin dicapai dapat dikategorikan menjadi 3 kawasan domain yaitu: (1) domain kognitif mencakup kemampuan intelektual mengenal lingkungan yang terdiri atas enam macam kemampuan yaitu: pengetahuan, pengalaman, penerapan, analisis, sistesis, dan penilaian; (2) domain afektif mencakup kemampuan-kemampuan emosional yaitu; kesadaran, partisipasi, penghayatan nilai, pengorganisasian nilai, dan karakterisasi diri; dan (3) domain psikomotor yaitu kemampuan-kemampuan motorik menggiatkan dan mengkoordinasikan gerakan terdiri dari; gerakan reflek, gerakan dasar, kemampuan perseptual, kemampuan jasmani, gerakan terlatih, dan gerakan nondiskursif.

Dengan mengetahui pentingnya pembelajaran PKN, maka tujuan-tujuan dalam pembelajaran diharapkan tercapai dengan optimal. Agar tujuannya dapat dicapai secara optimal diperlukan proses pembelajaran yang mengarah pada perbaikan yang ingin dicapai. Hal ini diperlukan ke profesionalan guru dalam membimbing peserta didik betul-betul menguasai materi, membuat perencanaan pembelajaran dengan sistematis, dan menggunakan metode atau model yang bervariasi dalam proses pembelajaran, sehingga dapat dengan baik mengantarkan peserta didiknya ketujuan yang ingin dicapai.

Berdasarkan hasil observasi yang dilakukan pada pembelajaran PKN kelas IV
SDN 07 Kabawetan pada ulangan semester 1 tahun ajaran 2014-2015 diperoleh keterangan ketuntasan hasil belajar siswa secara klasikal yakni rata-rata 6,16. Hal ini menunjukkan bahwa hasil belajar siswa masih rendah. tuntas secara individual apabila siswa memperoleh nilai 7,0 ke atas dan pembelajaran secara klasikal proses belajar mengajar dikatakan tuntas apabila siswa di kelas memperoleh nilai 7,0 ke atas sebanyak $75 \%$.

Rendahnya hasil belajar siswa ini disebabkan oleh beberapa faktor, antara lain: (1) selama proses pembelajaran guru hanya menyalurkan informasi, tanpa mengikut sertakan siswa (pasif); (2) siswa jarang diberikan kesempatan untuk memecahkan masalah sendiri; (3) cara penyampaian konsep oleh guru yang kurang sistematis; (4) pembelajaran yang dilakukan oleh guru masih bersifat konvensional yaitu hampir seluruh kegiatan pembelajaran dikendalikan oleh guru; (5) hasil belajar siswa rendah. Penerapan model pembelajaran yang dilakukan guru secara konvensional ini menyebabkan siswa menjadi pasif. Siswa hanya sebagai alat untuk transfer ilmu pengetahuan yang dimiliki oleh guru tanpa mengikut sertakan siswa dalam proses pembelajaran.

Untuk meningkatkan keaktifan dan hasil belajar siswa perlu diadakan perbaikan. Khususnya dalam proses pembelajaran diperlukan pelaksanaan pembelajaran, evaluasi serta pemilihan model dan teknik yang tepat sehingga anak tidak merasa jenuh pada saat kegiatan pembelajaran, dan belajar pun lebih bermakna dan menyenangka Dari berbagai literatur ditemukan salah satu metode dan teknik pembelajaran yang relevan dan dianggap efektif, yaitu dengan pendekatan siswa dengan teknik Berpikir, Berpasangan, Berbagi. Dipilihnya pendekatan siswa dengan teknik Berpikir, 
Berpasangan, Berbagi karena pembelajaran ini mempunyai keunggulan-keunggulan diantaranya memberikan kesempatan pada siswa untuk berpikir, menjawab, dan saling membantu satu sama lain .

Keunggulan lain dari pembelajaran ini adalah optimalisasi partisipasi siswa. Dengan metode klasikal yang memungkinkan hanya satu siswa maju dan membagikan hasilnya untuk seluruh kelas, teknik Berpikir, Berpasangan, dan Berbagi ini memberi kesempatan sedikitnya delapan kali lebih banyak kepada siswa untuk dikenali dan menunjukkan partisipasi mereka kepada orang lain.

Di samping mempunyai keunggulan, model pembelajaran teknik Berpikir, Berpasangan, dan Berbagi juga mempunyai kelemahan. Kelemahannya adalah: (1) metode pembelajaran Think Berpikir, Berpasangan, Berbagi belum banyak diterapkan di sekolah, (2) sangat memerlukan kemampuan dan keterampilan guru, waktu pembelajaran berlangsung guru melakukan intervensi secara maksimal, (3) menyusun bahan ajar mengubah kebiasaan siswa belajar dari yang dengan cara mendengarkan ceramah diganti dengan belajar berpikir memecahkan masalah secara kelompok.

\section{METODE}

Penelitian ini dilaksanakan di SDN 07 Kabawetan . Subyek penelitian ini adalah siswa kelas IV SDN 07 Kabawetan tahun ajaran 2014/2015. Pada kelas tersebut siswanya berjumlah 12 orang terdiri dari 6 siswa laki-laki dan 6 siswa perempuan. Mata pelajaran yang menjadi tujuan penelitian adalah pendidikan Kewarganegaraan $(\mathrm{PKN})$, dimana prestasi belajar anak masih belum memuaskan yaitu 5,82 .
Data yang terdapat pada laporan ini peneliti mengambil dari: (1) hasil observasi saat proses pembelajaran berlangsung; (2) lembar observasi evaluasi siswa yang terkumpul setelah proses pembelajaran selesai; (3) tes hasil belajar untuk menghimpun data tentang daya serap siswa dalam penguasaan bahan pelajaran PKN serta data prestasi belajar siswa.

Penenlitian Tindakan Kelas ini telah dilaksanakan dalam 3 siklus, setiap siklusnya terdiri dari empat tahap, yaitu: (1) Perencanaan (Planning); (2) Pelaksanaan tindakan (action); (3) observasi (observation); dan (4) Penilaian dan refleksi (reflection).

Data dianalisis dengan rata-rata nilai dan kriteria ketuntasan belajar berdasarkan penelitian acuan patokan. Menurut Depdiknas (2004). Siswa dikatakan tuntas belajar secara individual apabila siswa telah mencapai nilai 7,0 keatas secara klasikal proses belajar mengajar dikatakan tuntas bila siswa dikelas memperoleh nilai 7,0 keatas sebanyak $75 \%$.

\section{HASIL DAN PEMBAHASAN}

Deskripsi Hasil Penelitian perbaikan pembelajaran Pada siklus I dilaksanakan tes pada setiap pertemuan di akhir pembelajaran yang semuanya telah disusun dalam rencana pelaksanaan pembelajaran. Tes digunakan untuk mengetahui hasil belajar siswa dalam menerima materi pelajaran di setiap pertemuan.

Dari penelitian yang dilakukan oleh peneliti yang berlangsung sebanyak tiga siklus dengan menerpakan dapat meningkatkan keaktifan dan prestasi belajar siswa. Pada siklus I nilai hasil evaluasi rataratanya 6,16 dan hasil belajar klasikal $66,66 \%$, meningkat pada siklus II yaitu 7,12 dan hasil belajar klasikal 83,33\%, kemudian 
meningkat lagi pada siklus III niali rata-rata siswa adalah 8,02 sedangkan hasil belajar klasikal siswa mencapai 91,66,\%. Dari siklus ke siklus tampak ada peningkatan.

Berdasarkan peningkatan nilai tersebut dapat dikatakan bahwa pendekatan dapat meningkatkan keaktifan dan prestasi belajar siswa pada pembelajaran PKN dapat dikatakan berhasil, karena melaui diskusi kelompok dapat meningkatkan Pkn.

\section{Siklus I}

Berdasarkan hasil diskusi peneliti dengan teman sejawat, maka dapat disimpulkan bahwa kegiatan yang dilakukan peneliti dapat dikatakan cukup, walaupun telah mengalami peningkatan namun belum mencapai indikator keberhasilan seperti yang diharapkan pada penelitian ini.

Pada perbaikan pertama ini kekurangan yang muncul pada pembelajaran pertama adalah:

a. Siswa cendrung menjadi pendengar yang pasif pada saat proses pembelajaran berlangsung dikarenakan guru menggunakan bahasa ang sulit untuk dimengerti oleh siswa.

b. Guru kurang mengkondisikan kelas ke arah yang kondusif pada saat membagikan LDS sehingga ada beberapa siswa yang masih asik dengan kegiatannya masing ;

c. Guru tidak menggunakan media pembelajaran.

d. Guru kurang memberikan penjelasan terperinci kepada siswanya dalam menjelasakan cara mengerjakan tugas .

e. Tidak adanya pemantapan materi dan kesempatan bagi siswa untuk menanyakan hal-hal mengenai pelajaran yang belum mereka mengerti.

f. Hasil evaluasi siswa rendah

Ada pun kelebihan pada perbaikan1 adalah:
Dalam proses belajar mengajar siswa termotivasi dan semangat mengikuti pembelajaran.

Keseriusan dan keaktifan siswa dalam mengikuti proses pembelajaran meningkat. Hal ini dapat dilihat dari berkurangnya siswa yang sibuk dengan aktivitasnya masing-masing.

Prestasi belajar siswa telah mengalami peningkatan dibandingkan dengan sebelum mengalami tindakan. Pada siklus pertama ini, rata-rata hasil belajar siswanya adalah 6,16 . Indikator pembelajaran yang harus dicapai 7,0 Ini berarti rata-rata nilai siswa tersebut masih jauh dari indikator.Dan untuk ketuntasan belajar klasikalnya adalah $66,66 \%$.

\section{Siklus II}

Pada perbaikan kedua ini kekurangan yang muncul pada pembelajaran pertama adalah:

a) Hasil evaluasi siswa sudah semakin baik, tetapi ada beberapa siswa yang masih mendapat nilai rendah

b) Penggunaan media sudah optimal, tetapi masih belum tertib pada saat melibatkan siswa dalam pemanfaatan media

a. Pengelolaan kelas masih kurang maksimal

b. Guru tidak memberikan penghargaan kepada siswa yang telah melaksanakan pembelajaran dengan baik

Ada pun kelebihan pada perbaikan1 adalah: (1) dalam proses belajar mengajar siswa termotivasi dan semangat mengikuti pembelajaran. (2) Keseriusan dan keaktifan siswa dalam mengikuti proses pembelajaran meningkat. Hal ini dapat dilihat dari berkurangnya siswa yang sibuk dengan aktivitasnya masing-masing. (3) Siswa lebih senang belajar dengan menggunakan media pembelajaran. (4) Prestasi belajar siswa telah 
mengalami peningkatan dibandingkan dengan sebelum mengalami tindakan.

Pada siklus II nilai hasil evaluasi rataratanya meningkat dari 16,6 pada siklus I, menjadi 7,12 pada siklus II. Dan untuk ketuntasan belajar klasikalnya meningkat dari $66,66 \%$ menjadi $83,33 \%$.

\section{Siklus III}

Dengan menggunakan pendekatan keaktifan dan hasil belajar siswa dikatakan berhasil, dapat dilihat dari nilai hasil belajar siswa maupun nilai keaktifan siswa yang meningkat dari setiap siklus pembelajaran. Sebelum pendekatan siswa terhadap teknik Berpikir, Berpasangan, dan Berbagi nilai rata-rata belajar siswa dalam pembelajaran Pkn masih sangat rendah.

Dari penelitian yang dilakukan oleh peneliti yang berlangsung sebanyak tiga siklus dengan menggunakan meningkatkan keaktifan dan hasil belajar siswa. Pada siklus I nilai hasil evaluasi rata-ratanya 6,16 , kemudian meningkat menjadi 7,12 pada siklus II, dan akhirnya pada siklus III meningkat lagi menjadi 8,02. Dan untuk ketuntasan belajar klasikalnya meningkat dari $66,66 \%$ pada siklus I menjadi $83,33 \%$ pada siklus II, dan akhirnya menjadi $91,66 \%$ pada siklus III.

Berdasarkan peningkatan nilai tersebut dapat dikatakan bahwa pembelajaran Pkn dengan menggunakan pendekatan siswa terhadap teknik Berpikir, Berpasangan, Berbagi dapat dikatakan berhasil, karena melaui pembelajaran kelompok dapat meningkatkan pemahaman siswa terhadap konsep-konsep pembelajaran PKN. Keberhasilan PBM tersebut tidak terlepas dari kemampuan dan kerjasama peneliti dalam memanfaatkan berbagai komponen yang tersedia untuk menggali kreatifitas siswa, karena bagaimanapun pintarnya seorang guru tanpa disertai kompetensi guru dalam menggali kreatifitas siswa, PBM tidak akan optimal.

Dari data-data yang telah peneliti peroleh, maka kesimpulan dari penelitian ini bahwa melalui penerapan pendekatan siswa terhadap teknik Berpikir, Berpasangan, Berbagi mata pelajaran Pkn dapat meningkatkan keaktifan dan hasil belajar siswa. Dengan melihat kondisi tersebut, maka penggunaan siswa terhadap Teknik Berpikir,Berpasangan, Berbagi baik dilaksanakan pada proses belajar mengajar.

\section{SIMPULAN}

Berdasarkan hasil Penelitian Tindakan Kelas yang telah dilaksanakan dalam 3 siklus ini, maka dapat ditarik kesimpulan antara lain: (1) Strategi terbaik yang diperoleh dengan menerapkan pendekatan siswa terhadap teknik Berpikir,Berpasangan, Berbagi yang dimaksudkan adalah melalui langkah-langkah sebagai berikut: sebagai timbal balik dari serangkaian kegiatan yang dilakukan, yaitu dengan menugaskan siswa membaca-baca lagi materi selanjutnya; (2) Dengan menerapkan pendekatan siswa terhadap teknik Berpikir Berpasangan Berbagi dapat meningkatkan keaktifan dan partisipasi siswa dan guru dalam proses pembelajaran. Hal ini terlihat pada hasil ketuntasan belajar klasikal yaitu siklus I mencapai $66,66 \%$, dan nilai arata 6,16 , selanjutnya meningkat pada sikuls II yaitu ketuntasan belajar klasikal mencapai 83,33\% dan nilai rata-rata 7,12 , dan akhirnya meningkat lagi pada siklus III yaitu ketuntasan belajar klasikal mencapai $91,66 \%$ dan nilai rata-rata 8,02 ; (3) Penerapan pendekatan siswa terhadap teknik Berpikir,Berpasangan, Berbagi pada mata pelajaran PKN dapat meningkatkan hasil belajar siswa kelas IV SDN 07 Kabawetan

Setelah mengadakan Penilitian Tindakan Kelas yang dilaksanakan di kelas IV SDN 07 Kabawetan melalui penerapan pendekatan siswa terhadap teknik Berpikir 
,Berpasangan, Berbagi, maka melalui laporan hasil penelitian ini, penulis ingin menyampaikan beberapa saran, yaitu sebagai berikut: (1) guru yang ingin menggunakan pendekatan teknik Berpikir, Berpasangan, Berbagi pada pembelajaran PKn untuk menciptakan suasana kelas yang kondusif agar siswa termotivasi dan bersemangat dalam belajar; (2) lebih meningkatkan pembimbingan siswa dalam melaksanakan diskusi kelas supaya diperoleh hasil diskusi yang lebih baik dan terarah.

\section{DAFTAR PUSTAKA}

Arikunto, Suharsimi, dkk. 2007. Penelitian Tindakan Kelas. Jakarta: Bumi Aksara.

Depdikdas. 2004. Penelitian Dan Penilaian Pendidikan. Bandung: Sinar Baru Algensindo.

Depdikdas. 2005. Pedoman Evaluasi Proses dan Hasil Belajar PKN SD/MI. Jakarta: Departemen Pendidikan Nasional.

Depdikbud. Kamus Besar Bahasa Indonesia. Jakarta: Balai Pustaka.

Depdikdas. 2006 Pedoman Penyusunan KTSP di Sekolah Dasar. Jakarta: BSNP.
Depdikdas. 2006. Teori Belajar Dan Pembelajaran. Jakarta: Universitas Terbuka.

Depdiknas. 2006. Penilaian Hasil Belajar Mengajar. Bandung: Remaja Rosdakarya.

Depdiknas. 2007. Pedoman Penyusunan KTSP di Sekolah Dasar. Jakarta: BSNP.

Depdiknas. 2009. Penilaian Hasil Proses Belajar Mengajar. Bandung: Remaja Rosdakarya.

Hamalik, Oemar. 2007. Kurikulum dan Pembelajaran. Jakarta: Bumi Aksara.

Sumantri. 2006. Perkembangan Peserta Didik. Jakarta: Universitas Terbuka.

UU RI Nomor 20 Tahun 2003. Sistem Pendidikan Nasional. Bandung: Citra Umbara.

Winataputra, Udin S, dkk. 2002. Strategi Belajar Mengajar. Jakarta: Universitas Terbuka.

Zuchdi, Darmiyati. 2010. Humanisasi Pendidikan. Bina Aksara: Yogyakarta. 